\title{
Optimal Low-Density Lipoprotein Cholesterol Levels In Adults Without Diabetes Mellitus: A Nationwide Population-Based Study Including More Than 4 Million Individuals From South Korea
}

\author{
Ji Hye Huh \\ Hallym University Sacred Heart Hospital
}

\section{Sang Wook Park}

Yonsei University Wonju College of Medicine

\section{Tae-Hwa Go}

Yonsei University Wonju College of Medicine

\section{Dae Ryong Kang}

Yonsei University Wonju College of Medicine

\section{Sang-Hak Lee}

Yonsei University College of Medicine

Jang Young Kim ( $\nabla$ kimjang713@gmail.com )

Yonsei University Wonju College of Medicine https://orcid.org/0000-0002-0813-7082

\section{Original investigation}

Keywords: low-density lipoprotein cholesterol, impaired fasting glucose, cardiovascular disease, mortality, glucose level

Posted Date: August 24th, 2021

DOI: https://doi.org/10.21203/rs.3.rs-818976/v1

License: (a) (1) This work is licensed under a Creative Commons Attribution 4.0 International License. Read Full License 


\section{Abstract}

Background: Although the strong association between low-density lipoprotein cholesterol (LDL-C) and cardiovascular disease (CVD) is well-known, the threshold LDL-C level at which the risk of CVD begins to increase in individuals without diabetes mellitus (DM) remains unknown. We aimed to evaluate the association between incident CVD and serum LDL-C levels with or without statin use in individuals without DM.

Methods: We identified 4,182,117 individuals without previous CVD who underwent a health screening examination in 2009 and 2011 from the Korean National Health Insurance Cohort database. The primary endpoint was a composite of cardiovascular deaths, myocardial infarction (MI) cases, and ischemic stroke cases.

Results: During the median follow-up of 6 years, there were 51,961 CVD events that included 17,392 Ml cases, 33,779 ischemic stroke cases, and 2,039 cardiovascular deaths. The LDL-C levels that were associated with an increased risk of CVD were $\geq 100$ $\mathrm{mg} / \mathrm{dL}$ in non-statin users and $\geq 130 \mathrm{mg} / \mathrm{dL}$ in statin users. However, even in individuals with lower LDL-C levels, all those with fasting plasma glucose (FPG) levels $\geq 110 \mathrm{mg} / \mathrm{dL}$ had a significantly higher risk of CVD.

Conclusions: We demonstrated that LDL-C levels $\geq 100 \mathrm{mg} / \mathrm{dL}$ were correlated with an increased risk of CVD in individuals without DM and a history of CVD. We found that a glucose, cholesterol interaction increased CVD risk, and modestly elevated FPG levels $(110-125 \mathrm{mg} / \mathrm{dL})$ were associated with a higher CVD risk even in individuals with well-controlled LDL-C levels.

\section{Background}

Cardiovascular disease (CVD) is the leading cause of mortality globally and accounted for $31.4 \%$ of all deaths in 2012. In developed countries, age-adjusted cardiovascular mortality rates are declining; however, CVD remains the leading cause of mortality due to the rapid aging of the population [1]. Low-density lipoprotein cholesterol (LDL-C) is considered to be a major causative factor in the development of atherosclerotic CVD (ASCVD). Numerous studies have robustly demonstrated that reductions in plasma LDL-C concentrations by lipid-lowering agents are strongly associated with the reduced risk of incident CVD [2, 3]. Most current guidelines include the LDL-C level as a primary indicator for initiating and adjusting lipid-lowering interventions. However, these guidelines were set based on data from randomized controlled trials that investigated specific LDL-C targets for adjustments in the statin dose or from a small group of highly selected studies. Few longitudinal large-scale epidemiological studies have investigated the optimal LDL-C range for the lowest risk of CVD, especially in individuals without a prior history of CVD and diabetes mellitus (DM).

Hyperglycemia and a high LDL-C level have been considered major risk factors for CVD [4]. Patients with DM have a 2-4 times higher risk of CVD and cardiovascular mortality than the general population. Individuals with DM have a higher risk of the presence of small dense LDL particles than those without DM, even at identical plasma LDL-C levels. Therefore, the current guidelines regarding lipid management recommend the use of statins according to the LDL-C levels to prevent CVD in most patients with DM. However, considering the direct effect of high plasma glucose levels on CVD independent of LDL-C levels, optimal LDL-C goals for primary prevention may differ according to the glucose levels, even in individuals without DM. Nevertheless, trials that investigated the LDL-C target for the primary prevention of CVD have been performed among both patients with DM and individuals without DM [5], as well as among different ethnic groups [6]. Also, these previous studies did not consider the possible synergistic effects between higher plasma glucose levels and higher LDL-C levels.

In this study, we aimed to identify the optimal LDL-C levels associated with the lowest risk of CVD incidence in individuals without DM. We also evaluated whether fasting plasma glucose (FPG) levels magnify the risk of CVD associated with LDL-C levels in individuals without DM. Moreover, we classified the study population into statin users and non-users to investigate the optimal LDL$\mathrm{C}$ level for the primary prevention of CVD in each glycemic status classification. For this analysis, we used large-scale nationwide cohort data from the Korean National Health Insurance System (NHIS) database, which represents the entire Korean population.

\section{Methods}

\section{Study population}


In our cohort study, we used data from the NHIS, which is a government program that was implemented in 2002 and includes data on approximately $98 \%$ of the Korean population. Participants are entitled to a general health screening program every two years. Standardized self-reported questionnaires on medical history, lifestyle habits, anthropometric and blood pressure measurements, and regular laboratory tests using blood and urine samples are all part of the screening [7]. Our research-specific database included data from 2009 to 2011 for participants aged 19-69 years who underwent at least two general health screening programs during this period. To exclude participants who experienced myocardial infarction (MI) or ischemic stroke, those who had the following International Classification of Diseases, $10^{\text {th }}$ Revision (ICD-10) codes (as the main diagnosis or sub-diagnosis at baseline) were not included: 121, 122, 123, 163, or 164. We excluded those who were aged <40 years in 2009 and did not participate in a general health screening program in 2009. Thus, 4,709,862 participants were eligible for this analysis [8]. Participants who had missing variables regarding cholesterol and fasting glucose levels and were already diagnosed with DM (FPG level of $\geq 126 \mathrm{mg} / \mathrm{dL}$ or at least one claim for the prescription of hypoglycemic drugs per year, including insulin, under the ICD-10 codes E11-14) at baseline were excluded [9]. We also excluded those who had a serum glucose level of $70 \mathrm{mg} / \mathrm{dL}$ and died before 2014 or those who died due to unknown causes. Finally, 4,182,117 participants were included at baseline (Additional file 1). This study was approved by the Institutional Review Board of Yonsei University Wonju College of Medicine, Republic of Korea (no. CR318356). As the study was conducted using anonymous and de-identified data, informed consent from the participants was not obtained.

\section{Measurements and definitions}

The NHIS data included sex, age, body mass index (BMI), height, weight, waist circumference, blood pressure, and lifestyle-related behaviors, such as the frequency of alcohol consumption per week, smoking status, and regular exercise. Regular exercise was defined as performing more than 30 minutes of moderate physical activity at least five times per week or more than 20 minutes of strenuous physical activity at least three times per week. The income level was dichotomized at the lowest $25 \%$. Blood samples for measuring serum glucose, creatinine, and lipid levels were drawn after an overnight fast. Blood samples for measuring total cholesterol, high-density lipoprotein cholesterol (HDL-C), triglyceride (TG), and FPG levels were obtained at the health examinations after the participants fasted for at least 8 hours. LDL-C levels were calculated using the Friedewald formula: LDL-C = total cholesterol - HDL-C - (TG/5). Hypertension was defined as a systolic/diastolic blood pressure of $\geq 140 / 90 \mathrm{~mm} \mathrm{Hg}$ or at least one claim for antihypertensive medication prescriptions per year under the ICD-10 codes I10-I15. We defined a statin user as a person who had been prescribed statins in 2009-2011.

\section{Study outcomes and follow-up}

Participants who received two or more health screenings between 2009 and 2011 and were evaluated for primary outcomes during the follow-up period from 2014 to 2017 were included in the current study. During the follow-up period, the primary endpoint was cardiovascular events, which were described as a composite of incident cardiovascular deaths, Ml cases, and ischemic stroke cases. To minimize the influence of possible "reverse causation," we excluded participants with cardiovascular events that occurred within 3 years after baseline measurements. The ICD-10 codes were used for the diagnoses. MI was determined by recording the ICD-10 codes I21 or I22 at least twice during hospitalization for at least 4 days. Ischemic stroke was diagnosed based on the ICD-10 codes 163 or 164 that were registered during a 4-day hospital stay with claims for brain magnetic resonance imaging or brain computerized tomography [10]. The Korea National Statistical Office provided nationwide death certificate data for the follow-up analyses of cardiovascular deaths. The research was deemed complete if the participants' cardiovascular events occurred or the end of the follow-up period, whichever occurred first.

\section{Statistical analysis}

For each group, the continuous variables are presented as means and standard deviations, and the categorical variables are presented as frequencies and percentages. The participants were classified into six groups according to the following plasma LDL-C concentrations at baseline: $<70,70-99,100-129,130-159,160-189$, and $\geq 190 \mathrm{mg} / \mathrm{dL}$. The hazard ratios (HRs) and $95 \%$ confidence intervals (Cls) for incident CVD according to the categories of LDL-C were obtained using multivariable Cox proportional hazard models using the 70-99 mg/dL category as the reference after adjusting for age, sex, BMI, smoking status, alcohol consumption, regular exercise, income, and hypertension. We also investigated the risk of CVD according to LDL-C categories within the FPG strata. We analyzed the data using SAS version 9.4 (SAS Institute, Inc., Cary, NC) and R version 3.5.1 (R Foundation for Statistical Computing, Vienna, Austria). 


\section{Results}

\section{Baseline characteristics of the participants}

The NHIS data of a total of 4,182,117 participants from 2009 to 2011 were analyzed. The mean age of the participants was 51.1 years and $2,037,288(48.7 \%)$ participants were male. Overall, $16.7 \%$ of the participants used statins. Table 1 summarizes the baseline characteristics of the cohort groups according to the baseline LDL-C concentrations $(<70,70-99,100-129,130-159,160-$ 189 , and $\geq 190 \mathrm{mg} / \mathrm{dL}$ ). The proportion of male participants gradually increased from the lowest to the highest LDL-C categories. Participants in the highest LDL-C category (LDL-C levels $\geq 190 \mathrm{mg} / \mathrm{dL}$ ) tended to be older, have a higher BMl, and were more likely to take statins than those in the other LDL-C categories. Patients with a low LDL-C level were more likely to be female, current smokers, and heavy drinkers. The HDL-C levels and blood pressure measurements were similar across the six LDL-C categories.

\section{Risk of CVD according to the LDL-C categories}

During the median follow-up of about 6 years, there were 51,961 incident CVD events that included 17,392 cases of MI, 33,779 cases of ischemic stroke, and 2,039 cardiovascular deaths. There was a linear relationship between the LDL-C levels and CVD risk in the study population (Figure 1). The number of events, incidence, and HRs for CVD increased significantly in the higher LDL-C categories (Table 2). Using an LDL-C level of 70-99 mg/dL as the reference group, an LDL-C level of $\geq 100 \mathrm{mg} / \mathrm{dL}$ was associated with a significantly higher risk of CVD. In the multivariable analysis, the adjusted HRs (95\% Cls) for CVD in the < $70,100-129,130-159$, 160-189, and $\geq 190 \mathrm{mg} / \mathrm{dL}$ LDL-C categories were 1.02 (0.97-1.07), 1.09 (1.07-1.12), 1.30 (1.26-1.33), 1.51 (1.46-1.56), and 2.01 (1.89-2.14), respectively, compared with the $70-99 \mathrm{mg} / \mathrm{dL}$ LDL-C category. An LDL-C level of $\geq 100 \mathrm{mg} / \mathrm{dL}$ was associated with a significantly greater risk of CVD in non-statin users. The risk of CVD increased linearly from an LDL-C level $\geq 130 \mathrm{mg} / \mathrm{dL}$ in statin users compared to non-statin users. When this association was stratified by the type of cardiovascular event, LDL-C levels $\geq 100$ $\mathrm{mg} / \mathrm{dL}$ in non-statin users and $\geq 130 \mathrm{mg} / \mathrm{dL}$ in statin users were significantly associated with a higher risk of MI (Additional File 2). LDL-C levels $\geq 100 \mathrm{mg} / \mathrm{dL}$ in non-statin users and $\geq 190 \mathrm{mg} / \mathrm{dL}$ in statin users were correlated with a significantly higher risk of ischemic stroke. LDL-C levels $\geq 130 \mathrm{mg} / \mathrm{dL}$ in non-statin users and $\geq 190 \mathrm{mg} / \mathrm{dL}$ in statin users were associated with a significantly higher risk of cardiovascular deaths.

\section{Risk of CVD according to the LDL-C categories within the FPG strata}

We also analyzed the incidence values and HRs of CVD according to the LDL-C categories and stratified based on the FPG levels (70-90, 90-99, 100-109, and 110-125 mg/dL) (Table 3 and Figure 2). In all the FPG categories, we observed that the risk of CVD gradually increased as the LDL-C levels increased. Using the FPG category 70-99 mg/dL and LDL-C category 70-99 mg/dL as references, the CVD risk in the higher LDL-C group increased with worsening glycemic status. Moreover, even in participants with lower LDL-C levels, all those with FPG levels $\geq 110 \mathrm{mg} / \mathrm{dL}$ had a significantly higher risk of CVD than participants in the reference group. However, the higher risk of CVD in those with high LDL-C and high FPG levels was more attenuated in statin users than in nonstatin users (Figure 2).

\section{Discussion}

We evaluated the risk of incident CVD according to the LDL-C and FPG levels in participants without DM. We observed significant positive associations between the increased risk of CVD and high LDL-C levels in participants without DM, and the risk of CVD increased in participants without DM who had LDL-C levels $\geq 100 \mathrm{mg} / \mathrm{dL}$. We demonstrated that elevations in the FPG levels, even in the same LDL-C category, were associated with an increased risk of CVD. The risk of CVD increased more significantly in participants with FPG levels $\geq 110 \mathrm{mg} / \mathrm{dL}$ than in those in the other FPG categories. These findings suggested that elevations in the FPG and LDL-C levels independently contributed to the increased risk of CVD in participants without DM. To the best of our knowledge, this was the first nationwide study to investigate the optimal ranges of LDL-C that were associated with the lowest risk of CVD in East Asian adults without DM.

Previous epidemiological investigations have consistently demonstrated a strong positive, continuous, independent, and graded relationship between LDL-C levels and the incidence of CVD [11, 12]. Furthermore, recent meta-analyses of Mendelian randomization studies involving over 300,000 participants and 80,000 CVD cases provided convincing evidence regarding the causal correlation between LDL-C levels and the risk of ASCVD. Moreover, they showed that the causal impact of LDL-C levels on ASCVD might 
essentially be independent of the mechanism by which LDL-C levels are "lowered" [13]. Therefore, most international guidelines suggest strategies for managing LDL-C levels and setting LDL-C targets for the primary prevention of CVD. These guidelines consider DM to be a major risk factor for CVD and recommend the use of statins, regardless of the LDL-C levels, for the prevention of CVD in patients with DM [14-16]. However, the implementation of guidelines among members of the general population, especially among those without DM, has been a challenge for a long time. The American College of Cardiology/American Heart Association (ACC/AHA) guidelines removed specific target LDL-C levels since 2013 and emphasized a strategy of fixed-dose statin therapy based on cardiovascular risk in individuals without DM [14]. However, calculating the ASCVD risk is challenging due to the lack of time and complexities in clinical calculations. Moreover, this ASCVD risk calculator was designed based on data mainly from populations other than those from East Asia. Considering the established strong graded relationship between LDL-C levels and incident CVD, determining the optimal LDL-C range for the primary prevention of CVD in individuals without DM is needed in the Asian population.

The present study found that among participants without DM and a history of CVD, there was an increased risk of CVD in those with LDL-C levels $\geq 100 \mathrm{mg} / \mathrm{dL}$ This cut-off value was in line with that recommended by several international guidelines. The 2019 European Society of Cardiology/European Atherosclerotic Society guidelines suggest an LDL-C goal of $<116 \mathrm{mg} / \mathrm{dL}$ for the primary prevention of CVD in individuals with a low risk of CVD [16]. However, guidelines for dyslipidemia management in Korea suggest an LDL-C goal of $<130 \mathrm{mg} / \mathrm{dL}$ in individuals without DM and a moderate CVD risk, and $<160 \mathrm{mg} / \mathrm{dL}$ in individuals without DM and a low CVD risk [15]. The suggested target LDL-C levels according to the Korean guidelines in individuals without DM were significantly higher than those in our study (LDL-C levels $<100 \mathrm{mg} / \mathrm{dL}$ ). However, the Korean dyslipidemia guidelines were made based on data from other countries. Further prospective randomized controlled studies are warranted to determine the optimal LDL-C levels for the initiation of pharmacological intervention for the primary prevention of CVD in Korean adults without DM.

In the current study, we observed a graded positive trend for CVD risk starting from an LDL-C level of $100 \mathrm{mg} / \mathrm{dL}$, which increased for the higher LDL-C categories among participants who were non-statin users. The risk of CVD was higher whose LDL-C levels were $\geq$ $130 \mathrm{mg} / \mathrm{dL}$ in statin users than in those in the LDL-C reference group. From these results, we suggest that the uptitration of statins may be considered if LDL-C levels are $\geq 130 \mathrm{mg} / \mathrm{dL}$ during statin treatment, with consideration of the CVD risk in individuals without DM. Furthermore, the risk of CVD was relatively more attenuated in statin users than in non-statin users, even in the same LDL-C categories. The attenuated CVD risk in statin users was prominent in those in the higher LDL-C and FPG categories. It demonstrated the benefit of using statin for the primary prevention of CVD, regardless of the LDL-C levels in individuals without DM. This finding was consistent with those of previous primary prevention trials that demonstrated the benefits of statin therapy [17]. These studies showed that statins can reduce CVD risk through pleiotropic effects, including the inhibition of inflammation $[6,18]$.

We found that modestly elevated FPG levels (110-125 mg/dL), even it is not suitable level for diagnosing diabetes, were independently associated with a higher risk of CVD compared to the reference groups (FPG level of 70-99 mg/dL and LDL-C level of 70-99 mg/dL). A higher risk of CVD in participants with modestly elevated FPG levels was still observed even when their LDL-C levels were low $(70 \mathrm{mg} / \mathrm{dL})$. This suggested that well-controlled LDL-C levels might not be protective against a higher CVD risk in individuals with modestly elevated FPG levels. Moreover, we observed that the combination of higher FPG and LDL-C levels synergistically elevated the risk of CVD in participants without DM. This finding was consistent with the biological synergistic interaction between glucose and cholesterol levels reported in previous studies $[19,20]$. There are some possible biological mechanisms that support the interaction between glucose and LDL-C. It is widely believed that the oxidation of LDL-C plays an important role in atherogenesis, and excess circulating glucose levels might facilitate cholesterol peroxidation [21]. It was found that DM might be related to oxidative stress, which is linked to atherogenesis [22-24]. This biological interaction indicates that optimal LDL-C goals might differ according to glucose levels, which might be clinically significant. Our findings warrant a clinical trial to determine whether using glucose levels to advise about cholesterol control would improve outcomes. Our findings indicated that the target LDL-C goal for the primary prevention of CVD should be lower, and more aggressive statin use may be considered in individuals with FPG levels of $110-125 \mathrm{mg} / \mathrm{dL}$, similar to those with $\mathrm{DM}$.

Our study had several limitations. First, as the NHIS database relies on the issuance of a diagnostic code for CVD by physicians, there might have been a risk of misdiagnosis, which might have contributed to the underestimation or overestimation of the prevalence of CVD. Second, day-to-day variabilities might have influenced the findings due to laboratory errors or biological variations, as we used the results of a single LDL-C and FPG test in the analyses. Additionally, as we could not directly measure LDL$C$ levels and used the Friedewald formula instead, it might have led to the underestimation of the LDL-C levels. Third, there was lack of data on antidyslipidemic medication use among our participants during the follow-up period. Over time, cholesterol levels can 
increase, which could have led to statin use even among non-users, thereby mitigating the observed risk of CVD. Fourth, we did not obtain data on changes in medications or interventions during the follow-up period. Furthermore, we did not account for many confounders in our study, such as genetic factors, medication use, and socioeconomic status, which might have influenced our results. Fifth, we could not calculate the 10-year risk of ASCVD due to lack of data and consider individual cardiovascular risks in our analysis. Finally, as the present study only included the Korean population, our findings could not be generalized to other ethnicities. However, the major strengths of the current study were its large sample size, with approximately 4,000,000 relatively healthy participants, and use of longitudinal data. Thus, our results reflect "real-world" evidence on the association of LDL-C levels with CVD risk in individuals without DM on a national scale.

\section{Conclusions}

In conclusion, we demonstrated that LDL-C levels $\geq 100 \mathrm{mg} / \mathrm{dL}$ increased the risk of CVD in individuals without DM. Furthermore, we found that a glucose-cholesterol interaction magnified the CVD risk even in those without DM, and the CVD risk was more attenuated in statin users than in non-statin users. We observed a graded positive trend in CVD risk starting from an LDL-C level of $100 \mathrm{mg} / \mathrm{dL}$, and this risk increased in the higher LDL-C categories. Thus, more active initiation of statin treatment for the primary prevention of CVD in Korean adults without DM can be considered when their LDL-C levels are $\geq 100 \mathrm{mg} / \mathrm{dL}$. Moreover, given that participants with modestly elevated FPG levels (especially FPG levels $\geq 110 \mathrm{mg} / \mathrm{dL}$ ) had a high risk of CVD after adjusting for confounders, even those with lower LDL-C levels, earlier initiation of statin treatment for the primary prevention of CVD may be considered for these participants. Further large-scale, long-term, follow-up randomized control studies are warranted to clearly determine the optimal LDL-C target for the primary prevention of CVD in individuals without DM.

\section{List Of Abbreviations}

cardiovascular disease (CVD), Low-density lipoprotein cholesterol (LDL-C), atherosclerotic cardiovascular disease (ASCVD)., diabetes mellitus (DM). fasting plasma glucose (FPG), National Health Insurance Service (NHIS), myocardial infarction (MI), International Classification of Diseases, $10^{\text {th }}$ Revision (ICD-10), body mass index (BMI), high-density lipoprotein cholesterol (HDL-C), triglyceride (TG), hazard ratios (HR), 95\% confidence interval (95\% Cl).

\section{Declarations}

Ethics approval and consent to participate: This study was approved by Institutional Review Board of Yonsei University Wonju College of Medicine, Republic of Korea (no. CR318356). Anonymous and de-identified information was used for analysis; therefore, informed consent was not obtained.

Consent for publication: Not applicable.

Availability of data and materials: The datasets generated and analyzed during the current study are not publicly available due to rule of Korea National health insurance system.

Competing interests: The authors declare that they have no competing interests.

Funding: This study was supported by a National Research Foundation of Korea grant funded by the Korean government (No. NRF2019R1G1A109408).

\section{Potential conflicts of interest related to project funding}

The study sponsor was not involved in the design of the study; the collection, analysis, and interpretation of data; writing the report; or the decision to submit the report for publication

\section{Authors' contributions:}

J.H.H. and S.W.P. conceived the study concept and design., T.G. and D.R.K. acquired data and performed statistical analyses. J.H.H., and S.W.P. wrote the first draft, and conducted the literature search. J.H.H., S.H.L and J.Y.K. analyzed and interpreted data. All authors contributed to critical revision of the manuscript and read and approved the final submitted version of the manuscript. J.Y.K. 
is the guarantor of this work and, as such, had full access to all the data in the study and takes responsibility for the integrity of the data and the accuracy of the data analysis.

Acknowledgements: The authors thank the staff at the Big Data Steering Department of the National Health Insurance Service for providing data and support.

\section{References}

1. Mozaffarian D, Benjamin EJ, Go AS, Arnett DK, Blaha MJ, Cushman M, de Ferranti S, Despres JP, Fullerton HJ, Howard VJ, et al. Heart disease and stroke statistics-2015 update: a report from the American Heart Association. Circulation. 2015;131(4):e29322.

2. Cholesterol Treatment Trialists C, Fulcher J, O'Connell R, Voysey M, Emberson J, Blackwell L, Mihaylova B, Simes J, Collins R, Kirby $A$, et al. Efficacy and safety of LDL-lowering therapy among men and women: meta-analysis of individual data from 174,000 participants in 27 randomised trials. Lancet. 2015;385(9976):1397-405.

3. Cholesterol Treatment Trialists C, Baigent C, Blackwell L, Emberson J, Holland LE, Reith C, Bhala N, Peto R, Barnes EH, Keech A, et al. Efficacy and safety of more intensive lowering of LDL cholesterol: a meta-analysis of data from 170,000 participants in 26 randomised trials. Lancet. 2010;376(9753):1670-81.

4. Chung JW, Park YS, Seo JE, Son Y, Oh CW, Lee CH, Nam JH, Lee JH, Son JW, Kim U, et al. Clinical Impact of Dysglycemia in Patients with an Acute Myocardial Infarction. Diabetes Metab J. 2021;45(2):270-4.

5. Yusuf S, Bosch J, Dagenais G, Zhu J, Xavier D, Liu L, Pais P, Lopez-Jaramillo P, Leiter LA, Dans A, et al. Cholesterol Lowering in Intermediate-Risk Persons without Cardiovascular Disease. N Engl J Med. 2016;374(21):2021-31.

6. Ridker PM, Danielson E, Fonseca FA, Genest J, Gotto AM Jr, Kastelein JJ, Koenig W, Libby P, Lorenzatti AJ, MacFadyen JG, et al. Rosuvastatin to prevent vascular events in men and women with elevated C-reactive protein. N Engl J Med. 2008;359(21):2195207.

7. Seong SC, Kim YY, Park SK, Khang YH, Kim HC, Park JH, Kang HJ, Do CH, Song JS, Lee EJ, et al. Cohort profile: the National Health Insurance Service-National Health Screening Cohort (NHIS-HEALS) in Korea. BMJ Open. 2017;7(9):e016640.

8. Jang YN, Lee JH, Moon JS, Kang DR, Park SY, Cho J, Kim JY, Huh JH. Metabolic Syndrome Severity Score for Predicting Cardiovascular Events: A Nationwide Population-Based Study from Korea. Diabetes Metab J 2021.

9. Lee JH, Han K, Huh JH. The sweet spot: fasting glucose, cardiovascular disease, and mortality in older adults with diabetes: a nationwide population-based study. Cardiovasc Diabetol. 2020;19(1):44.

10. Kim JH, Moon JS, Byun SJ, Lee JH, Kang DR, Sung KC, Kim JY, Huh JH. Fatty liver index and development of cardiovascular disease in Koreans without pre-existing myocardial infarction and ischemic stroke: a large population-based study. Cardiovasc Diabetol. 2020;19(1):51.

11. Emerging Risk Factors C, Di Angelantonio E, Gao P, Pennells L, Kaptoge S, Caslake M, Thompson A, Butterworth AS, Sarwar N, Wormser D, et al. Lipid-related markers and cardiovascular disease prediction. JAMA. 2012;307(23):2499-506.

12. Prospective Studies C, Lewington S, Whitlock G, Clarke R, Sherliker P, Emberson J, Halsey J, Qizilbash N, Peto R, Collins R. Blood cholesterol and vascular mortality by age, sex, and blood pressure: a meta-analysis of individual data from 61 prospective studies with 55,000 vascular deaths. Lancet. 2007;370(9602):1829-39.

13. Ference BA, Ginsberg HN, Graham I, Ray KK, Packard CJ, Bruckert E, Hegele RA, Krauss RM, Raal FJ, Schunkert H, et al. Lowdensity lipoproteins cause atherosclerotic cardiovascular disease. 1. Evidence from genetic, epidemiologic, and clinical studies. A consensus statement from the European Atherosclerosis Society Consensus Panel. Eur Heart J. 2017;38(32):2459-72.

14. Arnett DK, Blumenthal RS, Albert MA, Buroker AB, Goldberger ZD, Hahn EJ, Himmelfarb CD, Khera A, Lloyd-Jones D, McEvoy JW, et al. 2019 ACC/AHA Guideline on the Primary Prevention of Cardiovascular Disease: Executive Summary: A Report of the American College of Cardiology/American Heart Association Task Force on Clinical Practice Guidelines. Circulation. 2019;140(11):e563-95.

15. Rhee EJ, Kim HC, Kim JH, Lee EY, Kim BJ, Kim EM, Song Y, Lim JH, Kim HJ, Choi S, et al. 2018 Guidelines for the Management of Dyslipidemia in Korea. J Lipid Atheroscler. 2019;8(2):78-131. 
16. Corrigendum to: 2019 ESC Guidelines on diabetes, pre-diabetes, and cardiovascular diseases developed in collaboration with the EASD. Eur Heart J 2020, 41(45):4317.

17. Shepherd J, Cobbe SM, Ford I, Isles CG, Lorimer AR, MacFarlane PW, McKillop JH, Packard CJ. Prevention of coronary heart disease with pravastatin in men with hypercholesterolemia. West of Scotland Coronary Prevention Study Group. N Engl J Med. 1995;333(20):1301-7.

18. Kinlay S, Schwartz GG, Olsson AG, Rifai N, Leslie SJ, Sasiela WJ, Szarek M, Libby P, Ganz P. Myocardial Ischemia Reduction with Aggressive Cholesterol Lowering Study I: High-dose atorvastatin enhances the decline in inflammatory markers in patients with acute coronary syndromes in the MIRACL study. Circulation. 2003;108(13):1560-6.

19. Catapano AL, Maggi FM, Tragni E. Low density lipoprotein oxidation, antioxidants, and atherosclerosis. Curr Opin Cardiol. 2000;15(5):355-63.

20. Cohen HW, Hailpern SM, Alderman MH. Glucose-cholesterol interaction magnifies coronary heart disease risk for hypertensive patients. Hypertension. 2004;43(5):983-7.

21. Brownlee $M$, Cerami A, Vlassara $\mathrm{H}$. Advanced glycosylation end products in tissue and the biochemical basis of diabetic complications. N Engl J Med. 1988;318(20):1315-21.

22. Bonina FP, Leotta C, Scalia G, Puglia C, Trombetta D, Tringali G, Roccazzello AM, Rapisarda P, Saija A. Evaluation of oxidative stress in diabetic patients after supplementation with a standardised red orange extract. Diabetes Nutr Metab. 2002;15(1):14-9.

23. Yasunari K, Maeda K, Nakamura M, Yoshikawa J. Oxidative stress in leukocytes is a possible link between blood pressure, blood glucose, and C-reacting protein. Hypertension. 2002;39(3):777-80.

24. Davi G, Guagnano MT, Ciabattoni G, Basili S, Falco A, Marinopiccoli M, Nutini M, Sensi S, Patrono C. Platelet activation in obese women: role of inflammation and oxidant stress. JAMA. 2002;288(16):2008-14.

\section{Tables}

Table 1. Baseline characteristics of participants according to LDL-C concentrations 


\begin{tabular}{|c|c|c|c|c|c|c|c|c|}
\hline \multirow[t]{2}{*}{ Characteristics } & \multirow[t]{2}{*}{ Overall } & \multicolumn{6}{|l|}{ LDL-C (mg/dL) } & \multirow{2}{*}{$\begin{array}{l}P \text { for } \\
\text { trend }\end{array}$} \\
\hline & & $<70$ & $70-99$ & $100-129$ & $130-159$ & $\begin{array}{l}160- \\
189\end{array}$ & $190^{\geq}$ & \\
\hline $\mathbf{N}$ & $4,182,117$ & 158,167 & 954,421 & $1,710,682$ & $1,031,991$ & 274,485 & 52,371 & \\
\hline Age (years) & $51.1(7.9)$ & $50.6(8.2)$ & $50.2(8)$ & $50.9(7.9)$ & $51.9(7.7)$ & $\begin{array}{l}52.6 \\
(7.6)\end{array}$ & $\begin{array}{l}53.0 \\
(7.5)\end{array}$ & $<0.05$ \\
\hline $\mathrm{BMI}\left(\mathrm{kg} / \mathrm{m}^{2}\right)$ & $23.9(2.8)$ & $23.5(3)$ & $23.4(2.9)$ & $23.8(2.8)$ & $24.2(2.8)$ & $\begin{array}{l}24.4 \\
(2.7)\end{array}$ & $\begin{array}{l}24.6 \\
(2.8)\end{array}$ & $<0.05$ \\
\hline Sex (male) & $\begin{array}{l}2,037,288 \\
(48.7)\end{array}$ & $\begin{array}{l}53,001 \\
(33.5)\end{array}$ & $\begin{array}{l}437,295 \\
(45.8)\end{array}$ & $\begin{array}{l}831,486 \\
(48.6)\end{array}$ & $\begin{array}{l}529,958 \\
(51.4)\end{array}$ & $\begin{array}{l}121,073 \\
(44.1)\end{array}$ & $\begin{array}{l}20,235 \\
(38.6)\end{array}$ & $<0.05$ \\
\hline Systolic BP (mmHg) & $\begin{array}{l}122.6 \\
(12.5)\end{array}$ & $124.2(13.2)$ & $\begin{array}{l}121.9 \\
(12.7)\end{array}$ & $\begin{array}{l}122.3 \\
(12.4)\end{array}$ & $\begin{array}{l}123.2 \\
(12.3)\end{array}$ & $\begin{array}{l}123.7 \\
(12.3)\end{array}$ & $\begin{array}{l}124.2 \\
(12.7)\end{array}$ & $<0.05$ \\
\hline $\begin{array}{l}\text { Diastolic BP } \\
\text { (mmHg) }\end{array}$ & $76.7(8.3)$ & $77.8(8.8)$ & $76.3(8.5)$ & $76.6(8.3)$ & 77 (8.2) & $\begin{array}{l}77.3 \\
(8.2)\end{array}$ & $\begin{array}{l}77.5 \\
(8.4)\end{array}$ & $<0.05$ \\
\hline eGFR & $85.4(19.5)$ & 87 (19.7) & $86.7(19.6)$ & $85.5(19.5)$ & $84.3(19.3)$ & $\begin{array}{l}83.6 \\
(18.9)\end{array}$ & $\begin{array}{l}83.3 \\
(18.4)\end{array}$ & $<0.05$ \\
\hline $\begin{array}{l}\text { Fasting plasma } \\
\text { glucose (mg/dl) }\end{array}$ & $94.3(9.7)$ & $95.2(10.6)$ & $93.7(9.8)$ & $94.1(9.6)$ & $94.8(9.6)$ & $\begin{array}{l}95.6 \\
(9.7)\end{array}$ & $\begin{array}{l}96.1 \\
(9.9)\end{array}$ & $<0.05$ \\
\hline $\begin{array}{l}\text { Total } \\
\text { cholesterol (mg/dl) }\end{array}$ & $\begin{array}{l}199.8 \\
(31.7)\end{array}$ & $152.4(25.6)$ & $170.1(18)$ & $\begin{array}{l}195.3 \\
(16.3)\end{array}$ & $\begin{array}{l}223.2 \\
(15.6)\end{array}$ & $\begin{array}{l}252.8 \\
(15.7)\end{array}$ & $\begin{array}{l}290.0 \\
(26.0)\end{array}$ & $<0.05$ \\
\hline HDL-C (mg/dl) & $55.8(17.7)$ & $55.6(19.8)$ & $56.3(17.8)$ & $55.8(17.5)$ & $55.3(17.5)$ & $\begin{array}{l}55.3 \\
(17.9)\end{array}$ & $\begin{array}{l}55.7 \\
(20.1)\end{array}$ & $<0.05$ \\
\hline Triglycerides (mg/dl) & $132.8[77.9]$ & $194.7[156.7]$ & $132.1[87.8]$ & 126.8 [68.6] & 131.7 [62.6] & $\begin{array}{l}138.5 \\
(62.0)\end{array}$ & $\begin{array}{l}148.5 \\
(75.3)\end{array}$ & $<0.05$ \\
\hline Smoking status (\%) & & & & & & & & $<0.05$ \\
\hline Never smoker & $\begin{array}{l}2,614,379 \\
(62.5)\end{array}$ & $\begin{array}{l}77,620 \\
(49.1)\end{array}$ & $\begin{array}{l}577,272 \\
(60.5)\end{array}$ & $\begin{array}{l}1,076,249 \\
(62.9)\end{array}$ & $\begin{array}{l}664,294 \\
(64.4)\end{array}$ & $\begin{array}{l}182,791 \\
(66.6)\end{array}$ & $\begin{array}{l}36,153 \\
(69.0)\end{array}$ & \\
\hline Former smoker & $\begin{array}{l}676,404 \\
(16.2)\end{array}$ & $\begin{array}{l}27,934 \\
(17.7)\end{array}$ & $\begin{array}{l}156,145 \\
(16.4)\end{array}$ & $\begin{array}{l}283,181 \\
(16.6)\end{array}$ & $\begin{array}{l}164,072 \\
(15.9)\end{array}$ & $\begin{array}{l}38,842 \\
(14.2)\end{array}$ & $\begin{array}{l}6,230 \\
(11.9)\end{array}$ & \\
\hline Current smoker & $\begin{array}{l}891,125 \\
(21.3)\end{array}$ & $\begin{array}{l}52,604 \\
(33.3)\end{array}$ & $\begin{array}{l}220,956 \\
(23.2)\end{array}$ & $\begin{array}{l}351,155 \\
(20.5)\end{array}$ & $\begin{array}{l}203,582 \\
(19.7)\end{array}$ & $\begin{array}{l}52,840 \\
(19.3)\end{array}$ & $\begin{array}{l}9,988 \\
(19.1)\end{array}$ & \\
\hline $\begin{array}{l}\text { Alcohol } \\
\text { consumption }\end{array}$ & & & & & & & & $<0.05$ \\
\hline$\leq 2$ days/week & $\begin{array}{l}3,609,708 \\
(86.3)\end{array}$ & $\begin{array}{l}114,502 \\
(72.4)\end{array}$ & $\begin{array}{l}794,956 \\
(83.3)\end{array}$ & $\begin{array}{l}1,485,657 \\
(86.9)\end{array}$ & $\begin{array}{l}918,232 \\
(89)\end{array}$ & $\begin{array}{l}248,541 \\
(90.6)\end{array}$ & $\begin{array}{l}47,820 \\
(91.3)\end{array}$ & \\
\hline 3-4 days/week & $\begin{array}{l}405,491 \\
(9.7)\end{array}$ & $\begin{array}{l}27,970 \\
(17.7)\end{array}$ & $\begin{array}{l}110,844 \\
(11.6)\end{array}$ & $\begin{array}{l}161,468 \\
(9.4)\end{array}$ & $\begin{array}{l}83,063 \\
(8.1)\end{array}$ & $\begin{array}{l}18,874 \\
(6.9)\end{array}$ & $\begin{array}{l}3,272 \\
(6.3)\end{array}$ & \\
\hline$\geq 5$ days/week & $\begin{array}{l}166,669 \\
(4.0)\end{array}$ & $15,684(9.9)$ & $\begin{array}{l}48,568 \\
(5.1)\end{array}$ & $\begin{array}{l}63,444 \\
(3.7)\end{array}$ & $30,641(3)$ & $\begin{array}{l}7,056 \\
(2.6)\end{array}$ & $\begin{array}{l}1,276 \\
(2.4)\end{array}$ & \\
\hline Income (lower 25\%) & $\begin{array}{l}870,665 \\
(21.1)\end{array}$ & $\begin{array}{l}32,854 \\
(21.0)\end{array}$ & $\begin{array}{l}201,380 \\
(21.3)\end{array}$ & $\begin{array}{l}356,338 \\
(21.1)\end{array}$ & $\begin{array}{l}211,823 \\
(20.8)\end{array}$ & $\begin{array}{l}56,917 \\
(21.0)\end{array}$ & $\begin{array}{l}11,353 \\
(21.9)\end{array}$ & $<0.05$ \\
\hline Regular exercise (\%) & $\begin{array}{l}1,434,239 \\
(34.3)\end{array}$ & $\begin{array}{l}53,243 \\
(33.7)\end{array}$ & $\begin{array}{l}325,431 \\
(34.1)\end{array}$ & $\begin{array}{l}591,656 \\
(34.6)\end{array}$ & $\begin{array}{l}354,645 \\
(34.4)\end{array}$ & $\begin{array}{l}92,432 \\
(33.7)\end{array}$ & $\begin{array}{l}16,832 \\
(32.1)\end{array}$ & $<0.05$ \\
\hline Hypertension (\%) & $\begin{array}{l}1,474,782 \\
(35.3)\end{array}$ & $67,978(43)$ & $\begin{array}{l}337,057 \\
(35.3)\end{array}$ & $\begin{array}{l}594,109 \\
(34.7)\end{array}$ & $\begin{array}{l}362,237 \\
(35.1)\end{array}$ & $\begin{array}{l}94,897 \\
(34.6)\end{array}$ & $\begin{array}{l}18,504 \\
(35.3)\end{array}$ & $<0.05$ \\
\hline $\begin{array}{l}\text { Medication for } \\
\text { statin (\%) }\end{array}$ & $\begin{array}{l}699,882 \\
(16.7)\end{array}$ & 32525 (20.6) & $\begin{array}{l}116728 \\
(12.2)\end{array}$ & $\begin{array}{l}196774 \\
(11.5)\end{array}$ & $\begin{array}{l}210196 \\
(20.4)\end{array}$ & $\begin{array}{l}81,596 \\
(29.7)\end{array}$ & $\begin{array}{l}15,599 \\
(29.8)\end{array}$ & $<0.05$ \\
\hline
\end{tabular}


Data are mean (standard deviation), median [interquartile range], or percentage

Abbreviations: BMI, body mass index; BP, blood pressure; HDL-C, high-density lipoprotein-cholesterol; LDL-C, low-density lipoprotein cholesterol.

Table 2. Risk of primary outcome according to the baseline LDL-C levels excluding subjects who died within 2 yers of follow-up

\begin{tabular}{|c|c|c|c|c|c|c|}
\hline Statin use & $\begin{array}{l}\mathrm{LDL-C} \\
(\mathrm{mg} / \mathrm{dL})\end{array}$ & $\begin{array}{l}\text { Person- } \\
\text { years }\end{array}$ & $\begin{array}{l}\text { Number of } \\
\text { events }\end{array}$ & $\begin{array}{l}\text { Incident rate } \\
(10,000 \text { person years })\end{array}$ & $\begin{array}{l}\text { Age- } \\
\text { adjusted } \\
\mathrm{HR} \\
(95 \% \mathrm{Cl})\end{array}$ & $\begin{array}{l}\text { Multivariable adjusted HR } \\
(95 \% \mathrm{Cl}) \#\end{array}$ \\
\hline \multirow[t]{6}{*}{ Overall } & $<70$ mg/dL & 1278498 & 2079 & 16.26 & $\begin{array}{l}1.1(1.05- \\
1.15)\end{array}$ & $1.02(0.97-1.07)$ \\
\hline & $\begin{array}{l}70-99 \\
\mathrm{mg} / \mathrm{dL}\end{array}$ & 7753135 & 10189 & 13.14 & $\begin{array}{l}1.00 \\
\text { (Reference) }\end{array}$ & 1.00 (Reference) \\
\hline & $\begin{array}{l}100- \\
129 \mathrm{mg} / \mathrm{dL}\end{array}$ & 13934274 & 19674 & 14.12 & $\begin{array}{l}1.07(1.05- \\
1.10)\end{array}$ & $1.09(1.07-1.12)$ \\
\hline & $\begin{array}{l}130- \\
159 \mathrm{mg} / \mathrm{dL}\end{array}$ & 8420637 & 14410 & 17.11 & $\begin{array}{l}1.28(1.25- \\
1.31)\end{array}$ & $1.30(1.26-1.33)$ \\
\hline & $\begin{array}{l}160- \\
189 \mathrm{mg} / \mathrm{dL}\end{array}$ & 2241436 & 4467 & 19.93 & $\begin{array}{l}1.50(1.45- \\
1.56)\end{array}$ & $1.51(1.46-1.56)$ \\
\hline & $\begin{array}{l}\geq 190 \\
\mathrm{mg} / \mathrm{dL}\end{array}$ & 427148 & 1142 & 26.74 & $\begin{array}{l}2.07(1.95- \\
2.20)\end{array}$ & $2.01(1.89-2.14)$ \\
\hline \multirow[t]{6}{*}{$\begin{array}{l}\text { Statin non- } \\
\text { user }\end{array}$} & $<70$ mg/dL & 1011432 & 1381 & 13.65 & $\begin{array}{l}1.07(1.01- \\
1.14)\end{array}$ & $1.01(0.95-1.07)$ \\
\hline & $\begin{array}{l}70-99 \\
\mathrm{mg} / \mathrm{dL}\end{array}$ & 6788255 & 7876 & 11.60 & $\begin{array}{l}1.00 \\
\text { (Reference) }\end{array}$ & 1.00 (Reference) \\
\hline & $\begin{array}{l}100- \\
129 \mathrm{mg} / \mathrm{dL}\end{array}$ & 12303761 & 16121 & 13.10 & $\begin{array}{l}1.10(1.08- \\
1.13)\end{array}$ & $1.11(1.08-1.15)$ \\
\hline & $\begin{array}{l}130- \\
159 \mathrm{mg} / \mathrm{dL}\end{array}$ & 6679456 & 10924 & 16.35 & $\begin{array}{l}1.36(1.32- \\
1.40)\end{array}$ & $1.37(1.33-1.41)$ \\
\hline & $\begin{array}{l}160- \\
189 \mathrm{mg} / \mathrm{dL}\end{array}$ & 1310427 & 2613 & 19.94 & $\begin{array}{l}1.69(1.62- \\
1.77)\end{array}$ & $1.69(1.61-1.76)$ \\
\hline & $\begin{array}{l}\geq 190 \\
\mathrm{mg} / \mathrm{dL}\end{array}$ & 170941 & 505 & 29.54 & $\begin{array}{l}2.58(2.36- \\
2.83)\end{array}$ & $2.47(2.26-2.70)$ \\
\hline \multirow[t]{6}{*}{ Statin user } & $<70 \mathrm{mg} / \mathrm{dL}$ & 267066 & 698 & 26.14 & $\begin{array}{l}1.03(0.94- \\
1.12)\end{array}$ & $0.99(0.91-1.08)$ \\
\hline & $\begin{array}{l}70-99 \\
\mathrm{mg} / \mathrm{dL}\end{array}$ & 964879 & 2313 & 23.97 & $\begin{array}{l}1.00 \\
\text { (Reference) }\end{array}$ & 1.00 (Reference) \\
\hline & $\begin{array}{l}100- \\
129 \mathrm{mg} / \mathrm{dL}\end{array}$ & 1630513 & 3553 & 21.79 & $\begin{array}{l}0.99(0.94- \\
1.04)\end{array}$ & $1.02(0.97-1.07)$ \\
\hline & $\begin{array}{l}130- \\
159 \mathrm{mg} / \mathrm{dL}\end{array}$ & 1741181 & 3486 & 20.02 & $\begin{array}{l}0.99(0.94- \\
1.04)\end{array}$ & $1.06(1.00-1.11)$ \\
\hline & $\begin{array}{l}160- \\
189 \mathrm{mg} / \mathrm{dL}\end{array}$ & 931009 & 1854 & 19.91 & $\begin{array}{l}1.04(0.98- \\
1.10)\end{array}$ & $1.16(1.09-1.24)$ \\
\hline & $\begin{array}{l}\geq 190 \\
\mathrm{mg} / \mathrm{dL}\end{array}$ & 256206 & 637 & 24.86 & $\begin{array}{l}1.36(1.25- \\
1.49)\end{array}$ & $1.51(1.38-1.66)$ \\
\hline
\end{tabular}

\# adjusted for age, sex, body mass index, smoking status, alcohol consumption, regular exercise, income and hypertension LDL-C, low lipoprotein cholesterol; HR, hazard ratios 
Table 3. Risk of primary outcome according to the baseline LDL-C levels excluding subjects who died within 2 yers of follow-up stratified by fasting glucose level at baseline 


\begin{tabular}{|c|c|c|c|c|c|c|}
\hline $\begin{array}{l}\text { Glucose } \\
\text { (mg/dL) }\end{array}$ & $\begin{array}{l}\mathrm{LDL}-\mathrm{C} \\
(\mathrm{mg} / \mathrm{dL})\end{array}$ & $\begin{array}{l}\text { Person- } \\
\text { years }\end{array}$ & $\begin{array}{l}\text { Number of } \\
\text { events }\end{array}$ & $\begin{array}{l}\text { Incident rate } \\
\text { (10,000 person years) }\end{array}$ & $\begin{array}{l}\text { Age- } \\
\text { adjusted } \\
\text { HR } \\
(95 \% \mathrm{Cl})\end{array}$ & $\begin{array}{l}\text { Multivariable adjusted HR } \\
(95 \% \mathrm{Cl}) \#\end{array}$ \\
\hline \multirow[t]{6}{*}{$70-90 \mathrm{mg} / \mathrm{dL}$} & $<70 \mathrm{mg} / \mathrm{dL}$ & 421783.9 & 568 & 13.47 & $\begin{array}{l}1.20(1.10- \\
1.31)\end{array}$ & $1.05(0.96-1.15)$ \\
\hline & $\begin{array}{l}70-99 \\
\mathrm{mg} / \mathrm{dL}\end{array}$ & 2891630.2 & 3185 & 11.01 & $\begin{array}{l}1.00 \\
\text { (Reference) }\end{array}$ & 1.00 (Reference) \\
\hline & $\begin{array}{l}100- \\
129 \mathrm{mg} / \mathrm{dL}\end{array}$ & 4877874.2 & 5948 & 12.19 & $\begin{array}{l}1.03(0.99- \\
1.08)\end{array}$ & $1.06(1.02-1.11)$ \\
\hline & $\begin{array}{l}130- \\
159 \mathrm{mg} / \mathrm{dL}\end{array}$ & 2664123 & 4067 & 15.27 & $\begin{array}{l}1.19(1.14- \\
1.25)\end{array}$ & $1.23(1.18-1.29)$ \\
\hline & $\begin{array}{l}160- \\
189 \mathrm{mg} / \mathrm{dL}\end{array}$ & 647856.6 & 1165 & 17.98 & $\begin{array}{l}1.33(1.25- \\
1.43)\end{array}$ & $1.40(1.31-1.50)$ \\
\hline & $\begin{array}{l}\geq 190 \\
\mathrm{mg} / \mathrm{dL}\end{array}$ & 117293.0 & 310 & 26.43 & $\begin{array}{l}1.94(1.73- \\
2.18)\end{array}$ & $2.03(1.81-2.29)$ \\
\hline \multirow[t]{6}{*}{$90-99 \mathrm{mg} / \mathrm{dL}$} & $<70 \mathrm{mg} / \mathrm{dL}$ & 469637.3 & 716 & 15.25 & $\begin{array}{l}1.23(1.14- \\
1.34)\end{array}$ & $0.99(0.91-1.07)$ \\
\hline & $\begin{array}{l}70-99 \\
\mathrm{mg} / \mathrm{dL}\end{array}$ & 3000266.7 & 3759 & 12.53 & $\begin{array}{l}1.04(1.00- \\
1.09)\end{array}$ & $0.96(0.92-1.01)$ \\
\hline & $\begin{array}{l}100- \\
129 \mathrm{mg} / \mathrm{dL}\end{array}$ & 5609484.6 & 7685 & 13.70 & $\begin{array}{l}1.09(1.05- \\
1.14)\end{array}$ & $1.06(1.02-1.10)$ \\
\hline & $\begin{array}{l}130- \\
159 \mathrm{mg} / \mathrm{dL}\end{array}$ & 3461224.7 & 5689 & 16.44 & $\begin{array}{l}1.24(1.19- \\
1.29)\end{array}$ & $1.23(1.18-1.29)$ \\
\hline & $\begin{array}{l}160- \\
189 \mathrm{mg} / \mathrm{dL}\end{array}$ & 921301.7 & 1806 & 19.60 & $\begin{array}{l}1.41(1.34- \\
1.50)\end{array}$ & $1.45(1.37-1.54)$ \\
\hline & $\begin{array}{l}\geq 190 \\
\mathrm{mg} / \mathrm{dL}\end{array}$ & 172577.0 & 457 & 26.48 & $\begin{array}{l}1.85(1.68- \\
2.04)\end{array}$ & $1.92(1.74-2.12)$ \\
\hline \multirow[t]{6}{*}{$\begin{array}{l}100-109 \\
\mathrm{mg} / \mathrm{dL}\end{array}$} & $<70 \mathrm{mg} / \mathrm{dL}$ & 257539.9 & 484 & 18.79 & $\begin{array}{l}1.42(1.29- \\
1.56)\end{array}$ & $1.05(0.95-1.15)$ \\
\hline & $\begin{array}{l}70-99 \\
\mathrm{mg} / \mathrm{dL}\end{array}$ & 1328820.6 & 2189 & 16.47 & $\begin{array}{l}1.26(1.20- \\
1.33)\end{array}$ & $1.05(1.00-1.11)$ \\
\hline & $\begin{array}{l}100- \\
129 \mathrm{mg} / \mathrm{dL}\end{array}$ & 2503745.5 & 4074 & 16.27 & $\begin{array}{l}1.23(1.17- \\
1.29)\end{array}$ & $1.09(1.04-1.14)$ \\
\hline & $\begin{array}{l}130- \\
159 \mathrm{mg} / \mathrm{dL}\end{array}$ & 1656633.4 & 3134 & 18.92 & $\begin{array}{l}1.38(1.31- \\
1.45)\end{array}$ & $1.27(1.21-1.34)$ \\
\hline & $\begin{array}{l}160- \\
189 \mathrm{mg} / \mathrm{dL}\end{array}$ & 478705.6 & 1004 & 20.97 & $\begin{array}{l}1.48(1.38- \\
1.59)\end{array}$ & $1.43(1.33-1.53)$ \\
\hline & $\begin{array}{l}\geq 190 \\
\mathrm{mg} / \mathrm{dL}\end{array}$ & 95308.2 & 244 & 25.60 & $\begin{array}{l}1.77(1.56- \\
2.02)\end{array}$ & $1.69(1.48-1.93)$ \\
\hline \multirow[t]{5}{*}{$\begin{array}{l}110-125 \\
\mathrm{mg} / \mathrm{dL}\end{array}$} & $<70 \mathrm{mg} / \mathrm{dL}$ & 129537.5 & 311 & 24.01 & $\begin{array}{l}1.73(1.54- \\
1.94)\end{array}$ & $1.17(1.04-1.32)$ \\
\hline & $\begin{array}{l}70-99 \\
\mathrm{mg} / \mathrm{dL}\end{array}$ & 532416.8 & 1056 & 19.83 & $\begin{array}{l}1.43(1.33- \\
1.53)\end{array}$ & $1.09(1.02-1.17)$ \\
\hline & $\begin{array}{l}100- \\
129 \mathrm{mg} / \mathrm{dL}\end{array}$ & 943169.8 & 1967 & 20.86 & $\begin{array}{l}1.49(1.41- \\
1.58)\end{array}$ & $1.22(1.15-1.29)$ \\
\hline & $\begin{array}{l}130- \\
159 \mathrm{mg} / \mathrm{dL}\end{array}$ & 638655.6 & 1520 & 23.80 & $\begin{array}{l}1.68(1.58- \\
1.79)\end{array}$ & $1.44(1.36-1.54)$ \\
\hline & $\begin{array}{l}160- \\
189 \mathrm{mg} / \mathrm{dL}\end{array}$ & 193572.2 & 492 & 25.42 & $\begin{array}{l}1.75(1.59- \\
1.93)\end{array}$ & $1.58(1.44-1.74)$ \\
\hline
\end{tabular}




$\begin{array}{lllll}\geq 190 & 41969.3 & 131 & 31.21 & 2.10(1.77- \\ \mathrm{mg} / \mathrm{dL} & & & 2.51) & \end{array}$

\# adjusted for age, sex, body mass index, smoking status, alcohol consumption, regular exercise, income and the presence of hypertension

LDL-C, low lipoprotein cholesterol; HR, hazard ratios

\section{Figures}

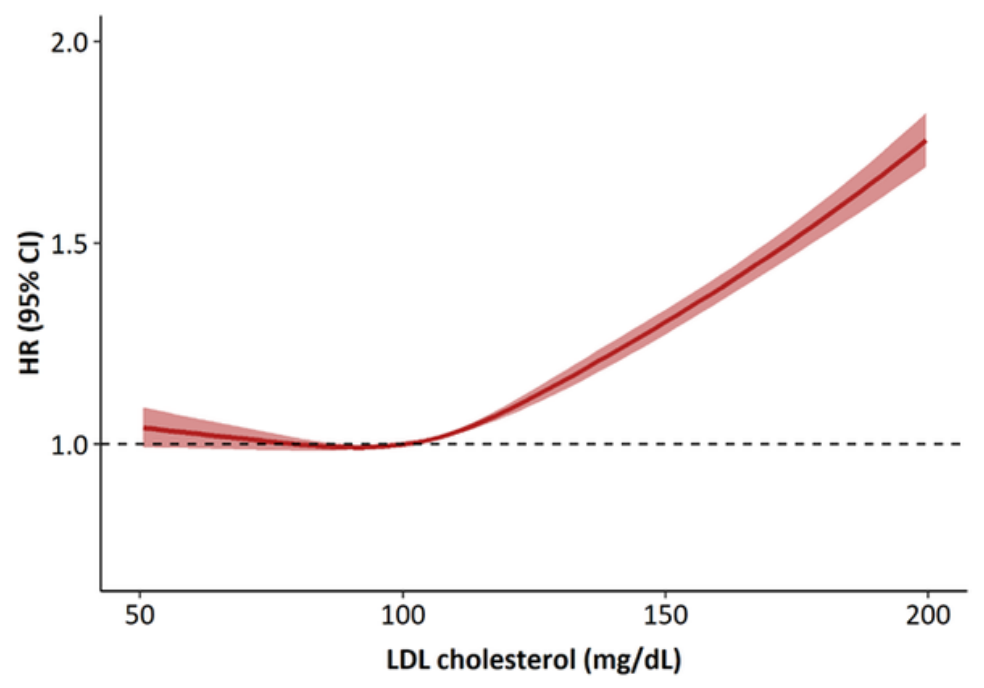

Figure 1

Hazard ratios for cardiovascular disease according to LDL cholesterol levels at baseline *Hazard ratios were calculated by Cox models after adjusting for age, sex, body mass index, smoking status, alcohol consumption, regular exercise, income and the presence of hypertension HR, hazard ratios 


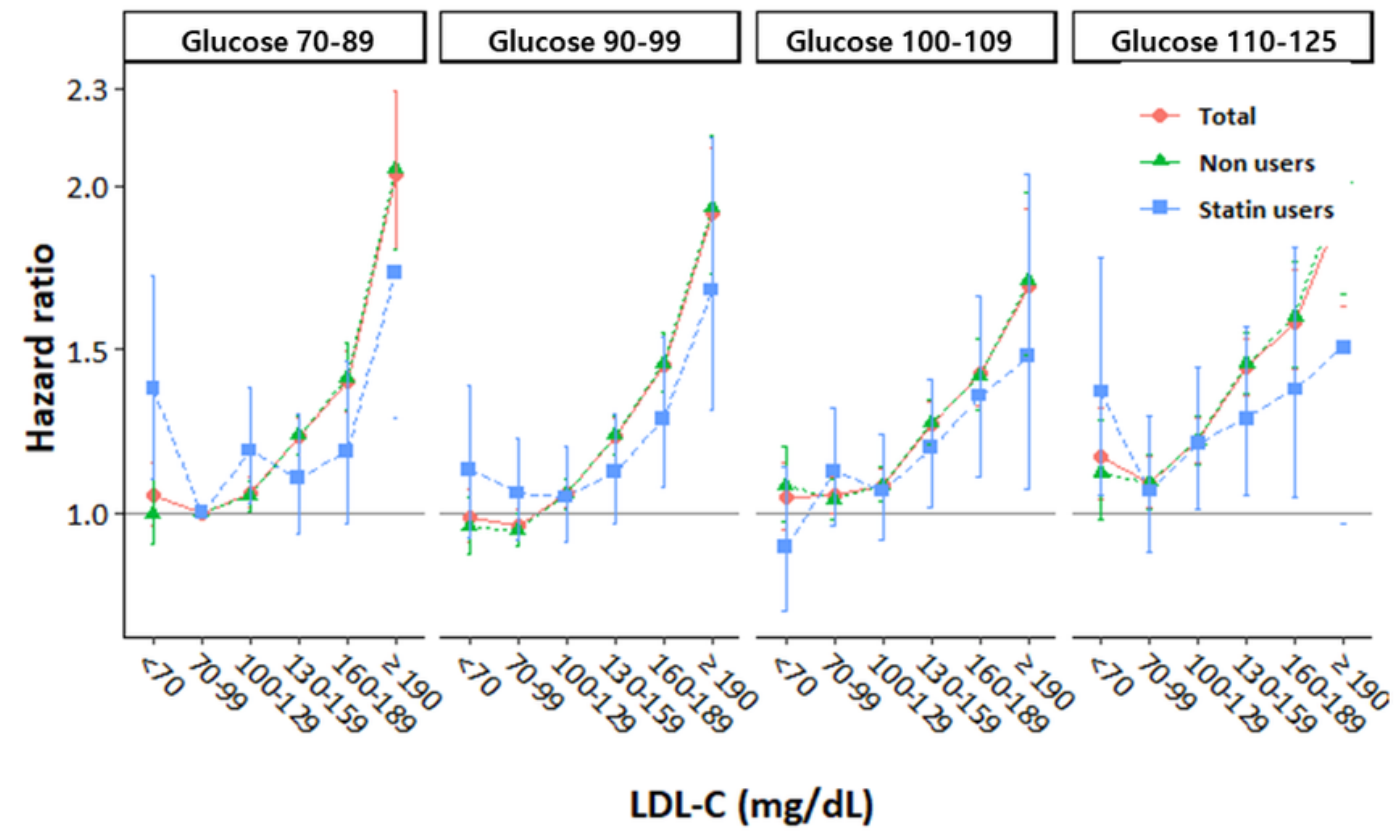

Figure 2

Hazard ratios for cardiovascular disease according to LDL cholesterol levels stratified by fasting glucose level at baseline.

\section{Supplementary Files}

This is a list of supplementary files associated with this preprint. Click to download.

- AdditionalFile1.png

- Additionalfile2.docx

- Supplementarytables.docx 